UDC: 620.3:661.693:6612.014

\title{
PHYSIOLOGICAL AND BIOCHEMICAL PROCESSES IN THE ORGANISMS OF RATS THAT WERE FED WITH DIFFERENT AMOUNTS OF GERMANIUM CITRATE
}

\author{
O. P. Dolaychuk, R. S. Fedoruk, I. I. Kovalchuk, S. Y. Kropyvka \\ inenbiol@mail.lviv.ua
}

Institute of Animal Biology NAAS, str. Vasyl Stus, 38, Lviv, 79034, Ukraine

Organic germanium compounds are characterized by a wide spectrum of effect on the organisms of people and animals and are used as a food supplement to enhance the immunological organism reactivity. However, using of the toxic inorganic forms as precursors for obtaining organic germanium compounds by chemical synthesis indicates the urgency of searching for the alternative ways to get them. This article presents the results of the study of the influence of different amounts of germanium citrate, which was obtained by electric impulse nanotechnology method, onto the physiological processes in rat organism to determine the optimal dose. The germanium citrate solutions with the concentrations of 10, 200, and $300 \mu \mathrm{g}$ of $\mathrm{Ge} / \mathrm{L}$ were used in the study. It was determined that feeding with germanium with the concentration of 10 $\mu \mathrm{g}$ of Ge/L did not show significant changes of the studied parameters. While an elevated concentration of hemoglobin, circulating immune complexes, and average weight molecules were observed in the blood of the rats, which were fed with germanium citrate with the concentrations of 200 and $300 \mu \mathrm{g}$ of Ge/L. Such changes may indicate the immunomodulatory properties of the germanium citrate. Probable decrease in the concentration of the lipid hydroperoxides and TBA-active products in the blood of the animals, which were fed with the germanium citrate with the concentrations of 200 and $300 \mu \mathrm{g}$ of Ge/L of water, was also found out. More effective physiological influence of the germanium onto the peroxidation processes was noticed in case of feeding its citrate with the concentrations of 200 and $300 \mu \mathrm{g}$ of Ge/L. So feeding with the germanium citrate, produced with the help of the nanotechnology method, improves the immunological indicators and reduces the intensity of the lipid peroxidation of the infant rats.

Keywords: GERMANIUM NANOAQUACITRATE; IMMUNOBIOLOGICAL INDICATORS; HAEMATOLOGY; RATS; BLOOD; INTERNAL ORGANS

\section{ФІЗІОЛОГО-БІОХІМІЧНІ ПРОЦЕСИ В ОРГАНІЗМІ ЩУРІВ ЗА ВИПОЮВАННЯ РІЗНОЇ КІЛЬКОСТІ ЦИТРАТУ ГЕРМАНІЮ}

\author{
О. П. Долайчук, Р. С. Федорук, І. І. Ковальчук, С. Й. Кропивка \\ inenbiol@mail.lviv.ua
}

Інститут біології тварин НААН, вул. В. Стуса, 38, м. Львів, 79034, Україна

\begin{abstract}
Органічні сполуки германію характеризуються широким спектром дії на організм людини $і$ тварин і використовуються в якості харчової добавки для підвищення імунобіологічної реактивності організму. Однак використання токсичних неорганічних форм в якості прекурсорів для отримання хімічним синтезом сполук органічного Германію вказує на актуальність пошуку альтернативних иляхів їхнього отримання. У иій статті наведено результати вивчення впливу різних кількостей циттрату германію, щзо був отриманий методом електроімпульсної нанотехнології, на фізіологічні процеси в організмі щурів з метою встановлення його оптимальної дози. У дослідженні використовувались розчини цчитрату германію у концентращіï 10, 200 i 300 мкг Gе/л. Встановлено, щзо випоювання Германію у концентрації 10 мкг Ge/л не показало вірогідних змін досліджуваних показників. У той час як у крові шурів, яким випоювали цичтрат германію у концентраціях 200 та 300 мкг Ge/л, спостерігалось підвищення концентрації гемоглобіну, цииркуюючих імунних комплексів i молекул середньої маси. Такі зміни можуть свідчити про імуномодулюючі властивості цчитрату
\end{abstract}


германію. Також встановлено вірогідне зниження концентрачії гідроперекисів ліпідів та ТБКактивних продуктів у крові тварин, яким випоювали цичтрат германію у концентрації 200 та 300 мкг $G e / л$ води. Більш ефективний фізіологічний вплив Германію на прочеси пероксидаиії відзначено за випоювання його ицитрату у концентрації 200 та 300 мкг Ge/л. Отюе, випоювання циитрату германію, виготовленого методом нанотехнологій, сприяє покращенню імунобіологічних показників та зниженню інтенсивності перекисного окиснення ліпідів щуренят.

\title{
Ключові слова: НАНОАКВАЦИТРАТ ГЕРМАНІЮ; ІМУНОБІОЛОГІЧНІ ПОКАЗНИКИ; ГЕМАТОЛОГІЯ; ЩУРІ; КРОВ; ВНУТРІШНІ ОРГАНИ
}

\section{ФИЗИОЛОГО-БИОХИМИЧЕСКИЕ ПРОЦЕССЫ В ОРГАНИЗМЕ КРЫС ПРИ ВИПАИВАНИИ РАЗНОГО КОЛИЧЕСТВА ЦИТРАТА ГЕРМАНИЯ}

\author{
О. П. Долайчук, Р. С. Федорук, И. И. Ковальчук, С. И. Кропьвка \\ inenbiol@mail.lviv.ua
}

Институт биологии животных НААН, ул. В. Стуса, 38, г. Львов, 79034, Украина

\begin{abstract}
Органические соединения германия характеризуются широким спектром действия на организм человека и животных и используются в качестве пищевой добавки для повышения иммунобиологической реактивности организма. Однако использование токсичных неорганических форм в качестве прекурсоров для получения химическим синтезом соединений органического германия, указывает на актуальность поиска альтернативных путей их получения. В данной статье приведены результаты изучения влияния разных количеств ичитрата германия, который был получен методом электроимпульсной нанотехнологии, на физиологические процессы в организме

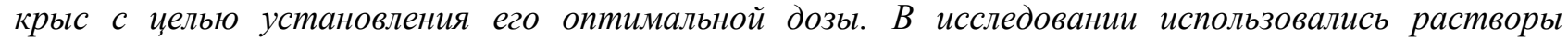
цитрата германия в концентрации 10, 200 и 300 мкг Ge/л. Установлено, что выпаивание Германия в концентрации 10 мкг Ge/л не показало достоверных изменений исследуемых показателей. В то время как в крови животных, которые получали с водой цитрат германия в концентрачиях 200 и 300 мкг $G e / л$, наблюдалось повышение конщентрации гемоглобина, циркулирующих иммунных комплексов $и$ молекул средней массы. Такие изменения могут свидетельствовать об иммуномодулирующих свойствах ичтрата германия. Также установлено достоверное снижение концентрация гидроперекисей липидов и ТБК-активных продуктов в крови животных, которые получали с водой ичитрат германия в концентрации 200 и 300 мкг Ge/л воды. Более эффективное физиологическое действие Германия на процессы пероксидации отмечено при выпаивании циттрата в конщентрации 200 и 300 мкг Ge/л. На основании полученных данных утверждается, что выпаивание циттрата германия, изготовленного методом нанотехнологии, способствует улучшению иммунобиологических показателей и снижению интенсивности перекисного окисления липидов крысят.
\end{abstract}

\section{Ключевые слова: НАНОАКВАЦИТРАТ ГЕРМАНИЯ; ИММУНОБИОЛОГИЧЕСКИЕ ПОКАЗАТЕЛИ; ГЕМАТОЛОГИЯ; КРЫСЫ; КРОВЬ; ВНУТРЕННИЕ ОРГАНЫ}

Germanium is a trace mineral that is found in the earth's crust in extremely small quantities, but some medicinal plants are characterized by its significant concentrations [1]. Despite the fact that germanium is not an essential element, it is characterized by a wide spectrum of biological effect on the organisms of people and animals. In particular, Ge as immunomodulator stimulates the activity of the natural killer cells and increases the production of gamma interferon and the antitumor immunity activity under the conditions of the carcinogenesis [2-5]. The study of the germanium influence on the immune system in pathological conditions showed that it increases the production of the macrophages by the organism and enhances the NK-lymphocyte functions [6]. Besides, Ge 
improves oxygenation of cells and cellular metabolism. This element reduces the activity of the peroxidation processes, increases the reduced glutathione level, glutathione peroxidase and superoxide dismutase activity because of the ability to transfer the electrons. Due to these properties the germanium organic compounds are used in medicine as immunomodulators, oncoprotectors, and to improve overall state of the organism as well as for cancer treatment [7-9]. The anticarcinogenic germanium properties are associated with its ability to increase immunization of tumor cells, or with the ability to inhibit proliferation, similar to cisplatin $[3,10]$. The literature data also describe cases of toxic, including death, influence of the germanium organic compounds. In particular, utilization of such compounds caused the nephrotic syndrome, renal failure, weight loss, appetite loss, anemia, and others [11]. Further studies showed that the organic germanium toxic effect is caused by the presence of the inorganic impurities (germanium dioxide, germanium tetrachloride), which are precursors for synthesizing its organic forms and are characterized by high toxicity [12-14]. For this reason, at present, it is important to obtain germanium in the bioavailable form without toxic effect development. Enrichment of the food supplements with Ge in the form of carboxylates obtained from the reaction of the Ge compounds with the citric acid is promising. However, the carboxylates, obtained by classical methods, do not always meet the requirements for purity of such salts if and when any byproducts of chemical reactions are found in them. Achievements of nanotechnologies and, in particular, development of the method of electric impulse nanotechnology, enabled to synthesize germanium citrate in an extremely chemically pure form in Ukraine (Kosinov V. M., Kaplunenko V. H. 2008). Currently research is being conducted to study the effects on animal organisms of trace elements obtained through nanotechnology [15-17]. However, the physiological processes in the organisms of people and animals were not studied under the influence of various doses of the germanium citrate, obtained by the nanotechnology method; this fact determined the choice of the direction of our study.

\section{Materials and methods}

The germanium citrate solution obtained by the nanotechnology method [18] was used for studies at the Ukrainian State Scientific Research Institute of Nanobiotechnologies and Resource Reservation.

The studies were conducted at the vivarium of the Institute of Animal Biology NAAS on the four groups of white laboratory rats. The female rats were divided into groups on the tenth day of lactation on the principle of counterparts; the offspring remained on rations of the female rats of the appropriate groups for the first four months of the life. The animals of the first group (control) were kept on a standard balanced ration throughout the study period. Animals of the second, third, and fourth groups (experimental subjects) received feed ration in accordance with the control group scheme and were fed with drinking water with germanium citrate with the concentrations of germanium citrate of 10,200 and $300 \mu \mathrm{g}$ of $\mathrm{Ge} / \mathrm{L}$ relatively. The four-month rats were subjected to euthanasia with the following decapitation to take blood and tissues for physiological and biochemical studies to determine the morphometric and mass indicators of the internal organs. Euthanasia was performed under light ether anesthesia, without violations of humane treatment of laboratory animals, with taking into account generally accepted bioethical standards, and in compliance with the international regulations concerning experimental studies [19]. The obtained digital materials were processed by the variation statistics method using the Student's test. Results are expressed as mean \pm standard error of mean (S.E.M.). The changes were considered significant if $\mathrm{P}<0.05$. The Excel 
computer program was used to make calculations.

The blood was examined for the number of red blood cells and white blood cells, hemoglobin, total protein, average weight molecules, circulating immune complexes concentration, activity of aminotransferases (ALT, AST) and content of the lipid peroxidation products (TBA-active products, lipid hydroperoxides) [20], the mass coefficients of the internal organs were also determined [21].

\section{Results and discussions}

The study of the hematological indicators showed a tendency to a higher number of white blood cells (by $8.3 \%$ in the third and $10.4 \%$ in the fourth group) and red blood cells, as well as hemoglobin contents by 4.6 and $8.4 \%$ in the third and fourth groups respectively with a significant difference for the rats which were fed with $300 \mu \mathrm{g}$ of $\mathrm{Ge} / \mathrm{L}$ of water (tabl. 1). The studied hematological parameters remained within the physiological limits for the animals of all experimental groups. The increase of the hemoglobin concentration at a time when there are more red blood cells in the blood of the animals, which were fed with the germanium citrate solution at the rate of $300 \mu \mathrm{g}$ of $\mathrm{Ge} / \mathrm{L}$ of water, may indicate strengthening of hematopoiesis and synthesis of hemoglobin.

Physiological data of blood of rats that were fed with different amounts of germanium citrate $(M \pm m, n=6)$

\begin{tabular}{|c|c|c|c|}
\hline Groups & White blood cells, $10^{9} / \mathrm{L}$ & Red blood cells, T/L & Hemoglobin, g/L \\
\hline I & $4.8 \pm 0.12$ & $5.43 \pm 0.11$ & $130.56 \pm 2.93$ \\
\hline II & $4.9 \pm 0.13$ & $5.42 \pm 0.10$ & $125.24 \pm 3.49$ \\
\hline III & $5.2 \pm 0.01$ & $5.46 \pm 0.13$ & $136.99 \pm 4.04$ \\
\hline IV & $5.3 \pm 0.15$ & $5.89 \pm 0.26$ & $141.99 \pm 4.03^{*}$ \\
\hline
\end{tabular}

Note: in this and in the next tables the significant change (compare with I group) is shown as $* \ldots \mathrm{p}<0,05 ; * *$ $-\mathrm{p}<0,01 ; * * *-\mathrm{p}<0,001$

Feeding the infant rats with the germanium led to an increase of the level of the average weight molecules, circulating immune complexes, and total protein in the blood, which was more apparent for the third and fourth animal groups (tabl. 2). However, the significant content increase of the average weight molecules (third group) and circulating immune complex (fourth group) was $14.3 \%$ when compared with the values before control. There also was a trend towards higher total protein content in the blood of the animals of the third and fourth experimental groups that were fed with germanium citrate solution with the concentrations of 200 and $300 \mu \mathrm{g}$ of Ge/L of water respectively if compared with its content before control. Such changes may be caused by the property of the germanium compounds to increase the immune system activity. In particular, it is known from the literature sources that $\mathrm{Ge}$, as immunomodulator, stimulates cellular immunity of the organisms of the animals [2-5].

Table 2

Immunobiological data of blood of rats that were fed with different amounts of germanium citrate $(M \pm m, n=6)$

\begin{tabular}{|c|c|c|c|}
\hline Groups & Average weight molecules, g/L & $\begin{array}{c}\text { Circulating immune complexes, } \\
\text { absorbance units }\end{array}$ & Total protein, g/L \\
\hline I & $0.35 \pm 0.008$ & $28.0 \pm 1.15$ & $61.56 \pm 1.76$ \\
\hline II & $0.36 \pm 0.010$ & $29.0 \pm 1.31$ & $61.17 \pm 1.22$ \\
\hline III & $0.40 \pm 0.005^{*}$ & $31.0 \pm 0.88$ & $66.53 \pm 1.84$ \\
\hline IV & $0.39 \pm 0.008$ & $32.0 \pm 1.09^{*}$ & $66.72 \pm 1.09$ \\
\hline
\end{tabular}


The probable intergroup differences of the lipid peroxidation indices in the blood of the four-month rats confirm this (tabl. 3). These data analysis indicates the apparent antioxidant action of $\mathrm{Ge}$ citrate in rat organism, which was accompanied by a decrease in the content of the TBA-active products and lipid hydroperoxides in the blood of the animals of all experimental groups. It is characteristic that the significantly lower content of these metabolites was in the blood of rats of the third and fourth groups but more effective physiological effect on the peroxidation processes was observed in the animals of the third group, which received $200 \mu \mathrm{g}$ of $\mathrm{Ge} / \mathrm{L}$ of water. While feeding with $10 \mu \mathrm{g}$ of $\mathrm{Ge} / \mathrm{L}$ was characterized by the higher content of the TBA-active products and lipid hydroperoxides in the blood of the rats of the second group, when compared with the third and fourth groups, but the level of these indicators was lower than in the blood of the animals in the control group. It is obviously that higher doses of the germanium citrate optimized the physiological processes in rats organisms from the inhibition of lipid peroxidation, that is also confirmed by the results of the studies of the other authors [22, 23].

Table 3

Content of the lipid peroxidation products of blood of rats that were fed with different amounts of germanium citrate $(M \pm m, n=6)$

\begin{tabular}{|c|c|c|}
\hline Groups & $\begin{array}{c}\text { TBA-active products, } \\
\mathrm{nmol} / \mathrm{ml}\end{array}$ & $\begin{array}{c}\text { Lipid hydroperoxides, } \\
\text { extinction units/ml }\end{array}$ \\
\hline I & $6.10 \pm 0.08$ & $1.85 \pm 0.05$ \\
\hline II & $5.92 \pm 0.06$ & $1.61 \pm 0.09$ \\
\hline III & $4.34 \pm 0.20^{*}$ & $1.17 \pm 0.07^{*}$ \\
\hline IV & $5.06 \pm 0.16^{*}$ & $1.39 \pm 0.02^{*}$ \\
\hline
\end{tabular}

It was also found out by the studies that there was a significant decline of the alanine aminotransferase blood activity by 8.9 and $15.1 \%$ respectively for the animals of the third and fourth groups that were fed with the solution with higher citrate germanium concentrations (tabl. 4). It is known from the literature sources that the germanium compounds have the ability to inhibit the activity of certain enzymes, particularly, the glutamate-oxaloacetate transaminases, lactate dehydrogenases, glutathione-s-transferases, and others. Such effects on the enzyme systems were observed after introduction of the significantly higher germanium concentrations (500-2000 mg/L) [24], when compared with the germanium citrate concentrations used in our studies. While the aspartate aminotransferase activity of the rats blood of the third and fourth groups was increased by 9.4 and $7.0 \%$ respectively with significant difference for the animals of the third group. The obtained results of the blood transaminase activity and their analysis indicate certain differences of the biological effect of various amounts of germanium citrate in the organisms of young rats during the first four months of their growth and development. It is believed that the applied higher doses of the germanium citrate cause an optimizing influence on the functional activity of the liver and protein metabolism in the organism, its growth and development.

Aminotransferases activity in blood of rats that were fed with different amounts of germanium citrate $(M \pm m, n=6)$

\begin{tabular}{|c|c|c|}
\hline Groups & ALT, $\mu \mathrm{kat} / \mathrm{L}$ & AST, $\mu \mathrm{kat} / \mathrm{L}$ \\
\hline I & $0.582 \pm 0.004$ & $0.771 \pm 0.022$ \\
\hline II & $0.599 \pm 0.008$ & $0.762 \pm 0.018$ \\
\hline III & $0.530 \pm 0.020^{*}$ & $0.844 \pm 0.013^{*}$ \\
\hline IV & $0.494 \pm 0.021^{*}$ & $0.825 \pm 0.033$ \\
\hline
\end{tabular}


The conducted killing of six fourmonth animals from each group showed the absence of hazardous or toxic effects of the applied low and high doses of the germanium citrate on the growth and development of the internal organs of the rats (tabl. 5). Determination of the mass coefficients of the heart, liver, pancreas, and testes of the animals of the control and experimental groups indicates their approximately equal values in the rats of all groups. However, the significantly higher mass coefficients of the kidneys of the animals of the third and fourth groups at a time when there are lower values for spleen may indicate a great influence of the germanium in the amount of 200 and $300 \mu \mathrm{g}$ to form internal organs in animals during the postnatal period, which in its turn may indicate the influence of the germanium citrate in the amount of 200 and $300 \mathrm{mg}$ on the fluid and electrolyte balance of the organism and its immune and hematopoietic capacity.

Table 5

\section{Mass coefficients of the internal organs of rats that were fed with different amounts of germanium citrate ( $\mathrm{g} / \mathrm{kg}$ live weight, $M \pm m, n=6-11$ )}

\begin{tabular}{|c|c|c|c|c|c|c|}
\hline Groups & Heart & Kidneys & Liver & Spleen & Pancreas & Testes \\
\hline I & $4.7 \pm 0.08$ & $8.8 \pm 0.26$ & $38.3 \pm 0.57$ & $3.8 \pm 0.10$ & $3.5 \pm 0.10$ & $12.1 \pm 0.13$ \\
\hline II & $4.9 \pm 0.05$ & $8.5 \pm 0.25$ & $38.3 \pm 0.47$ & $3.5 \pm 0.08^{*}$ & $3.7 \pm 0.07$ & $12.0 \pm 0.77$ \\
\hline III & $4.5 \pm 0.08$ & $9.9 \pm 0.08^{*}$ & $37.6 \pm 0.23$ & $3.2 \pm 0.03^{* * *}$ & $3.4 \pm 0.03$ & $12.3 \pm 0.13$ \\
\hline IV & $4.6 \pm 0.08$ & $10.1 \pm 0.11^{* *}$ & $38.2 \pm 0.38$ & $3.1 \pm 0.03^{* * *}$ & $3.6 \pm 0.07$ & $12.5 \pm 2.01$ \\
\hline
\end{tabular}

\section{Conclusions}

Feeding of rats starting from 10 days after their birth and up to the four months with the Ge citrate in the amount of 200 and $300 \mu \mathrm{g}$ of $\mathrm{Ge} / \mathrm{L}$ of water is characterized by activation of the hematopoiesis, immunological organism reactivity, and decrease of the lipid peroxidation processes in their blood. The biological effect of the applied amounts of the $\mathrm{Ge}$ is not the same, greater physiological effect was observed in the organisms of the rats that were fed with 200 and $300 \mu \mathrm{g}$ of $\mathrm{Ge} / \mathrm{L}$ of water. The mentioned Ge doses do not affect the growth and development of the heart, liver, pancreas, and testis but they increase the weight of the kidneys and decrease the mass coefficients of spleen of the four-month rats.

Prospects of further researches. It may be appropriate to study morphological and histological indicators of the internal organs of rats in the subsequent periods during application of the germanium and its combinations with the citrates of other tracer elements.
1. Gielen M, Tiekink E. R. T. Metallotherapeutic Drugs and Metal-based Diagnostic Agents: The Use of Metals in Medicine. Wiley, 2005. $638 \mathrm{p}$.

2. Shangguan G. Q., Zhang S. G., Ni J. Z. Synthesis, structures and antitumor activities of beta-phenolester propyl germanium sesquioxides. Chinese Chem Lett, 1995, 6, pp. 945-946.

3. Shangguan G., Xing F., Qu X., Mao J., Zhao D., Zhao X., Ren J. DNA binding specificity and cytotoxicity of novel antitumor agent Ge132 derivatives. Bioorg Med Chem Lett, 2005, 15, pp. 2962-2965.

4. Shangguan G. Q., Huang L. L., Qu M. G. The synthesis and cytotoxic activity of novel organogermanium sesquioxides with anthraquinone or naphthalene moiety. Chinese Chem Lett, 2007, 18, pp. 1347-1350.

5. Zhang C. L., Li T. H., Niu S. H., Wang R. F., Fu Z. L., Guo F. Q., Yang M. Synthesis and evaluation of novel organogermanium sesquioxides as antitumor agents. Bioinorg Chem Appl, 2009, article ID 908625, pp. 1-8.

6. Aso H., Suzuki F., Yamaguchi T., Hayashi Y., Ebina T., Ishida N. Induction of interferon and activation of NK cells and macrophages in mice by oral administration of Ge132, an organic germanium compound. Microbiol Immunol, 1985, 29, pp. 65-74. 
7. Mrema J. E., Slavik M., Davis J. Spirogermanium: a new drug with antimalarial activity against chloroquine-resistant Plasmodium falciparum. Int $J$ Clin Pharmacol Ther Toxicol, 1983, 21, pp. 167-171.

8. Slavik M., Blanc O., Davis J. Spirogermanium: a new investigational drug of novel structure and lack of bone marrow toxicity. Invest New Drugs, 1983, 1, pp. 225-234.

9. Ishiwata Y., Yokochi S., Suzuki E., Michishita H., Tashita A., Asano K., Mitani T., Kurono M. Effects of proxigermanium on interferon production and 2',5'-oligoadenylate synthetase activity in the lung of influenza virusinfected mice and in virus-infected human peripheral blood mononuclear cell cultures. ArzneiForschung, 1990, 40, pp. 896-899.

10. Suzuki F Antitumor mechanisms of carboxyethyl-germanium sesquioxide (Ge-132) in mice bearing Ehrlich ascites tumors. Gan To Kagaku Ryoho, 1987, 14, pp. 127-134.

11. Nagata N., Yoneyama T., Yanagida K., Ushio K., Yanagihara S., Matsubara O., Eishi Y. Accumulation of germanium in the tissues of a long-term user of germanium preparation died of acute renal failure. $J$ Toxicol Sci, 1985, 10, pp. 333-341.

12. Gerber G. B., Leonard A. Mutagenicity, carcinogenicity and teratogenicity of germanium compounds. Mutat Res-Rev Mutat, 1997, 387, pp. 141-146.

13. Lin C. H., Chen T. J., Hsieh Y. L., Jiang S. J, Chen S. S. Kinetics of germanium dioxide in rats. Toxicology, 1999, 132, pp. 147-153.

14. Tao S. H., Bolger P. M. Hazard assessment of germanium supplements. Regul Toxicol Pharmacol, 1997, 25, pp. 211-219.

15. Fedoruk R. S., Khomyn N. M., Khomyn M. M. Physiological and biochemical impact nanoparticles of chromium and selenium citrate in the body young rats. The Animal Biology, 2013, vol. 15, no. 4, pp. 141-149 (in Ukrainian).

16. Khomyn M. M., Fedoruk R. S. Antioxidant profile of organism and biological value of milk of cows in the first months of lactation under feeding by chromium and selenium citrate. The Animal Biology, 2013, vol. 15, no. 2, pp. 140-149 (in Ukrainian).

17. Lesyk Ya. V., Fedoryk R. S., Kropyvka S. J., Dolaychyk O. P. Physiological and biochemical parameters of blood and semen quality of rabbits, watering sulfur and chromium compounds. The Animal Biology, 2014, vol. 16, no. 1, pp. 104-111 (in Ukrainian).

18. Kosinov M.. V., Kaplunenko V. H. Method of metal carboxylates Nanotechnology get metal carboxylates". Patent U. no. 38391. 2009 (in Ukrainian).

19. European convention for the protection of vertebrate animals used for experim. and other scientific purposes. Coun. of Europe, Strasbourg, 1986, pp. 53.

20. Vlizlo V. V. Laboratory research methods in biology, animal husbandry and veterinary medicine. Lviv, SPOLOM, 2012. pp.355-368 (in Ukrainian).

21. Kotsyumbas I. Ya. Preclinical studies of veterinary medicines. Lviv: Triada plyus, 2006. 360 p. (In Ukrainian).

22. Yang M. K., Kim Y. G. Protective role of germanium-132 against paraquat-induced oxidative stress in the livers of senescenceaccelerated mice. J Toxicol Environ Health A., 1999, 12, 58 (5), pp. 289-297.

23. Xie W., Chen X., Yang K. Effects of selenium and germanium on lipid peroxidation in rats fed with low-selenium grain. Zhonghua $Y u$ Fang Yi Xue Za Zhi, 1996, 30 (2), pp. 88-90.

24. Furst A. Biological Testing of Germanium. Toxicology and industrial health, 1987, 3 (1) pp. 167-204. 